\title{
STRATEGI PELAYANAN PUBLIK DI KANTOR KECAMATAN KANDANGAN KABUPATEN KEDIRI
}

\author{
Public Service Strategy In Office Kecamatan Kandangan \\ Kediri Regency
}

\author{
Imam Fachruddin 1 \\ ${ }^{1}$ Magister Ilmu Administrasi Universitas Kadiri
}

\begin{abstract}
Abstrak
Penelitian ini bertujuan untuk mengetahui kinerja aparatur, Strategi peningkatan pelayanan publik di Kecamatan Kandangan Kabupaten Kediri, serta hambatan yang dihadpi untuk meningkatkan kukitas pelayanan publi di Kantor Kecamatan Kandangan Kabupaten Kediri. Penelitian ini adalah penelitian deskriptif dengan menggunakan pendekatan kualitatif. Teknik pengumpulan data dilakukan dengan teknik observasi, wawancara, dan dokumentasi. Teknik analisis data yang digunakan adalah model interaktif. Pemeriksaan keabsahan data dilakukan dengan triangulasi sumber dan metode. Memanfaatkan keterangan dari informan, penelitian ini menghailkan temuan : 1). Strategi pelayanan publik di Kantor Kecamatan Kandangan dilihat dari berbagai indikator yaitu penyediaan sarana dan prasarana fisik (tangible), sumberdaya aparatur yang handal (reliability), penyederhanaan peroses (simple process), daya tanggap (responsiveness) aparatur yang cukup, menyediakan ruang tunggu dan tempat parkir yang aman / jaminan (Assurance), dan empati (empathy) aparatur di Kecamatan Kandangan, rata-rata masyarakat menilai sudah relative baik. 2). Pendektan kepada masyarakat, meningkatkan profesionlisme apartur dan melengkapi sarana - prasarana merupakan strategi pemerintah Kabupaten Kediri dalam Meningkatkan Kualitas Penyelenggaraan Pelayanan Publik di kecamatan Kandangan.
\end{abstract}

Kata kunci: Aparatur; Kualitas Pelayanan Publik; Strategi dan Kantor Kecamatan Kandangan

\begin{abstract}
This study aims to determine the performance of the apparatus, the strategy of improving public services in Kandangan Subdistrict, Kediri Regency, as well as obstacles faced to improve public service capacity in the Kandangan District Office, Kediri Regency.This research is a descriptive study using a qualitative approach. Data collection techniques are carried out with observation, interview, and documentation techniques. Data analysis techniques used are interactive models. The validity of the data is done by triangulating the source and method. Utilizing the information from the informants, this study produced findings: 1). The public service strategy in the Kandangan District Office is seen from various indicators, namely the provision of tangible facilities and equipment, reliability, simplification of processes, simple responsiveness of the apparatus, providing waiting rooms and places. secure parking / assurance (Assurance), and empathy (empathy) apparatus in Kandangan Subdistrict, the average community considers it to be relatively good. 2). Sensitivity to the community, enhancing the professionalism of apartments and supplementing infrastructure - the strategy of the government of Kediri Regency in Improving the Quality of the Implementation of Public Services in Kandangan sub-district.
\end{abstract}

Keywords: Apparatus; Quality of Public Service; Strategy and Office of Kandangan Subdistrict

\section{A. PENDAHULUAN}

Kantor Kecamatan Kandangan merupakan bagian dari fasilitas pelayanan publik milik pemerintah yang dalam pelaksanaan akan melayani masyarakat yang ada, baik miskin maupun non miskin. Agar pelayanan yang diberikan Kantor Kecamatan Kandangan dapat bermanfaat bagi masyarakat, maka Kantor Kecamatan Kandangan melakukan inovasi dalam pelayanan ini. Dalam era desentralisasi, diharapkan ada perubahan pada Kantor Kecamatan Kandangan dalam kegiatannya, yaitu public private management. Public-private management di Kantor Kecamatan Kandangan, diadakan karena mempunyai tujuan untuk meningkatkan mutu pelayanan di wilayah kerja Kantor Kecamatan Kandangan yang sesuai dengan kebutuhan masyarakat, agar dapat tercapai tujuan tersebut maka Kantor Kecamatan Kandangan perlu mendapatkan dukungan dari 
para pegawai Kantor Kecamatan Kandangan , Masyarakat, dan Pemerintah Kabupaten Kediri.

Keberhasilan organisasi dalam mencapai tujuan tidak terlepas dari peran pegawai. Pegawai bukan semata obyek dalam pencapaian tujuan organisasi, tetapi juga menjadi subyek atau pelaku. Mereka dapat menjadi perencana, pelaksana dan pengendali yang selalu berperan aktif dalam mewujudkan tujuan organisasi, serta mempunyai pikiran, perasaan dan keinginan yang dapat mempengaruhi sikapnya terhadap pekerjaan. Menciptakan kinerja organisasi yang baik adalah tujuan dari setiap organisasi.

Berdasarkan kondisi diatas maka dapat diketahui bahwa pada organisasi yang diteliti, pencapaian kepuasan kerja memiliki akibat yang berbeda yaitu meningkatkan kinerja dan menurunkan kinerja, akan tetapi pada sebagian besar informen yang diteliti diketahui bahwa kepuasan kerja dapat meningkatkan kinerja. Di Kabupaten Kediri juga sudah disiapkan perangkat perundang-undangan yang mengatur tentang pelayanan di kantor pemerintah. Dalam mengatur tentang standart dan tata cara pelayanan pelayanan publik kepada masyarakat yang pada muaranya mengarah ke kualitas pelayanan dan kepuasan masyarakat.

Ironisnya, Kantor Kecamatan KandanganKabupaten Kediri selama ini belum dimanfaatkan oleh masyarakat secara optimal untuk pelayanan publik. Hal tersebut disebabkan masyarakat kurang begitu mengenal fungsi dan nama baik / image secara baik. Untuk itu, penelitian ini diberi judul "STRATEGI PELAYANAN PUBLIK DI KANTOR KECAMATAN KANDANGAN KABUPATEN KEDIRI".

Berdasarkan latar belakang dan uraian tersebut di atas, maka dapat disusun rumusan masalah penelitian dalam penelitian ini sebagai berikut :

1. Bagaimana strategi yang dilakukan aparatur di Kantor Kecamatan Kandangan Kabupaten Kediri.

2. Bagaimana strategi eksekutif (Bupati dan jajaran di bawahnya) dalam upaya peningkatan pelayanan publik di kantor Kecamatan Kandangan?.

\section{B. LANDASAN TEORITIS}

\subsection{Strategi}

Strategi merupakan aktivitas tertinggi yang biasanya disusun oleh dewan direksi dan dilaksanakan oleh pimpinan serta tim eksekutif organisasi tersebut. strategis memberikan arahan menyeluruh untuk organisasi dan terkait erat dengan bidang perilaku organisasi. Strategis berbicara tentang gambaran besar. Inti dari strategis adalah mengidentifikasi tujuan organisasi, sumber dayanya, dan bagaimana sumber daya yang ada tersebut dapat digunakan secara paling efektif untuk memenuhi tujuan strategis. strategis di saat ini harus memberikan fondasi dasar atau pedoman untuk pengambilan keputusan dalam organisasi. Ini adalah proses yang berkesinambungan dan terus-menerus. Rencana strategis organisasi merupakan dokumen hidup yang selalu dikunjungi dan kembali dikunjungi.Bahkan mungkin sampai perlu dianggap sebagaimana suatu cairan karena sifatnya yang terus harus dimodifikasi.Seiring dengan adanya informasi baru telah tersedia, dia harus digunakan untuk membuat penyesuaian dan revisi.

Menurut Thomas L.Wheelen - J. David Hunger strategi adalah serangkaian dari pada keputusan majerial dan kegiatankegiatan yang menentukan keberhasilan organisasi dalam jangka panjang. Kegiatan tersebut terdiri dari perumusan / perencanaan strategi, pelaksanaan / implementasi, dan evaluasi. Lingkungan dunia yang mengalami perubahan seperti adanya globalisasi, control masyarakat, perkembangan teknologi, memberikan dampak bagi perkembangan suatu negara maupun bisnis. Control masyarakat terhadap pelaksanaan kegiatan pemerintahan maupun organisasi, sehingga pemerintah maupun pemimpin organisasi tidak dapat membuat kebijakan yang mengabaikan kepentingan masyarakat. Oleh sebab itu dalam menjalankan kegiatannya perlu adanya keselarasan antara kompetensi yang dimiliki organisasi maupun pemerintah dengan lingkungan yang ada di luar organisasi (organisasi dan pemerintah). Sebelum melangkah lebih jauh tentang seberapa jauh peran stratejik dalam pengembangan organisasi, kita akan menyimak dulu pengertian dari stratejik itu sendiri, berikut beberapa ahli yang memberikan gambaran atau teori tentang stratejik itu sendiri.

Barney, 2007:27 strategis (strategic management) dapat dipahami sebagai proses 
pemilihan dan penerapan strategi-strategi. Sedangkan strategi adalah pola alokasi sumber daya yang memungkinkan organisasi-organisasi dapat mempertahankan kinerjanya. Grant, 2008:10 Strategi juga dapat diartikan sebagai keseluruhan rencana mengenai penggunaan sumber daya-sumber daya untuk menciptakan suatu posisi menguntungkan. Dengan kata lain, manajamen strategis terlibat dengan pengembangan dan implementasi strategistrategi dalam kerangka pengembangan keunggulan bersaing. Michael A. Hitt \& R. Duane Ireland \& Robert E. Hoslisson (2006,XV) strategis adalah proses untuk membantu organisasi dalam mengidentifikasi apa yang ingin mereka capai, dan bagaimana seharusnya mereka mencapai hasil yang bernilai. David 2005:5 Seni dan pengetahuan untuk merumuskan, mengimplementasikan and mengevaluasi keputusan lintas fungsional yang membuat organisasi mampu mencapai obyektifnya. Hunger dan Wheelen 2006:4 Serangkaian keputusan dan tindakan manajerial yang menentukan kinerja organisasi dalam jangka panjang.

Sedangkan Bambang Hariadi (2003 : 3) berpendapat bahwa strategis adalah suatu proses yang dirancang secara sistematis oleh untuk merumuskan strategi, menjalankan strategi dan mengevaluasi strategi dalam rangka menyediakan nilai - nilai yang terbaik bagi seluruh pelanggan untuk mewujudkan visi organisasi. Menurut Tunggal Amin Widjaja (2004), strategis terdiri dari sembilan tugas kritikal berikut ini:

1. Memformulasi misi (mission) organisasi termasuk pernyataan yang luas mengenai maksud (purpose), falsafah (philosophy) dan sasaran (goal).

2. Mengembangkan suatu profil organisasi yang merefleksi pada kondisi internal dan kemampuannya.

3. Menilai lingkungan eksternal organisasi, termasuk baik faktor kompetitif maupun faktor yang berhubungan dengan konteks umum.
4. Menganalisis opsi organisasi dengan menandingi sumber daya organisasi dengan lingkungan eksternalnya.

5. Mengidentifikasi opsi yang paling diiinginkan dengan menilai setiap opsi dipandang dari sudut misi organisasi.

6. Memilih sekumpulan tujuan jangka panjang dan strategi total (grand strategies) yang akan mencapai opsi yang paling diinginkan.

7. Mengembangkan tujuan tahunan dan strategi jangka pendek yang sesuai dengan kumpulan tujuan jangka panjang yang dipilih dari strategi secara keseluruhan (grand strategies).

8. Mengimplementasikan pilihan strategi dengan alat alokasi sumber daya yang dianggarkan yaitu memadani tugas tugas, manusia, struktur, teknologi dan menekankan sistem ganjaran.

9. Menilai keberhasilan proses strategik sebagai masukan untuk pengambilan keputusan di masa yang akan datang.

Dari definisi tersebut terdapat dua hal penting yang dapat disimpulkan, yaitu:

Strategik terdiri atas tiga proses:

1. Pembuatan Strategi, yang meliputi pengembnagan misi dan tujuan jangka panjang, mengidentifiksikan peluang dan ancaman dari luar serta kekuatan dan kelemahan organisasi, pengembangan alternatif-alternatif strategi dan penentuan strategi yang sesuai untuk diadopsi.

2. Penerapan strategi meliputi penentuan sasaran-sasaran operasional tahunan, kebijakan organisasi, memotovasi anggota dan mengalokasikan sumbersumber daya agar strategi yang telah ditetapkan dapat diimplementasikan.

3. Evaluasi/Kontrol strategi, mencakup usaha-usaha untuk memonitor seluruh hasil-hasil dari pembuatan dan penerapan strategi, termasuk mengukur kinerja individu dan organisasi serta mengambil langkahlangkah perbaikan jika diperlukan.

Strategik memfokuskan pada penyatuan/ penggabungan aspek-aspek pemasaran, riset dan pengembangan, keuangan/ akuntansi, operasional/ produksi dari sebuah organisasi. 


\subsection{Pelayanan publik}

Menurut Lembaga Administrasi Negara (2003 : 27) pada dasarnya terdapat dua paradigma dalam pelayanan publik pertama adalah paradigma pelayanan publik yang berorientasi pada pengelola pelayanan. Paradigma ini lebih bersifat birokratis, direktif, dan hanya memperhatikan / mengutamakan kepentingan pimpinan / organisasi pelayanan itu sendiri. Paradigma ini banyak mendapat keluhan dari masyarakat pengguna layanan karena kurang memperhatikan kepentingan masyarakat pengguna layanannya. Masyarakat sebagai pengguna layanan tidak memiliki kemampuan apapun untuk berkreasi, suka tidak suka, mau tidak mau, mereka harus tunduk kepada pengelola pelayanan. Seharusnya pelayanan publik dikelola dengan paradigma yang bersifat supportif dimana lebih memfokuskan diri pada kepentingan masyarakat pengguna layanan, pengelola harus mampu bersikap menjadi pelayan yang sadar untuk melayani dan bukan dilayani. Paradigma kedua merupakan paradigma yang digunakan dalam penelitian ini, yaitu paradigma pelayanan publik yang terfokus berorientasi pada kepuasan pengguna layanan (customer drivengovernment).

Customer driven government merupakan prinsip ke-enam dari sepuluh prinsip mewirausahakan birokrasi oleh David Osborne dan Ted Gaebler (1992).

Prinsip ini menguraikan bahwa pemerintahan yang berorientasi pelanggan adalah pemerintah yang memenuhi kebutuhan pengguna layanannya, bukan birokrasi. Kebanyakan organisasi pemerintah bahkan tidak tahu siapa pengguna layanan mereka. Mengapa demikian? Menurut Osborne dan Gaebler, logikanya sederhana, karena sebagian besar badan pemerintah tidak memperoleh dananya dari pengguna layanan (secara langsung). Disamping itu sebagian pelanggan mereka bersifat captive, pelanggan 'paksa', singkatnya para pengguna layanan mempunyai sedikit alternatif terhadap pelayanan yang disediakan oleh pemerintah. Oleh karena itu birokrasi sering mengabaikan para pengguna layanannya. Birokrat menganggap bahwa pelanggan mereka adalah eksekutif dan legislatif, karena dari sanalah mereka memperoleh dana secara langsung. Para pejabat birokrat yang diangkat, pada gilirannya, lebih berorientasi pada pejabat yang mengangkatnya atau kelompok kepentingan / partai. Jadi, sementara bisnis bersungguh-sungguh menyenangkan pelanggan, badan pemerintah mati-matian untuk menyenangkan kelompok kepentingan.

Budiono (2003 : 3) mendefinisikan pemerintah yang berorientasi pelanggan (customer driven government) yaitu pemerintah yang meletakkan pengguna layanan sebagai hal yang paling depan. Oleh karena itu, kepuasan pengguna layanan ditempatkan sebagai sasaran penyampaian tujuan, dengan mendengarkan suara pengguna layanan. Dengan memperhatikan kebutuhan dasar pengguna layanan, pemerintah lebih responsif dan inovatif. Lembaga Administrasi Negara (2003 : 27) memberikan ciri-ciri dari paradigma pelayanan customer driven government, antara lain sebagai berikut : (1) lebih fokus pada kegiatan fasilitasi untuk berkembangnya iklim yang kondusif bagi kegiatan pelayanan masyarakat; (2) lebih fokus pada pemberdayaan masyarakat; (3) fokus pada pencapaian visi, misi, tujuan, sasaran dan hasil (outcomes); (4) fokus pada kebutuhan dan keinginan masyarakat; (5) pada hal tertentu, organisasi pemberi layanan juga berperan untuk memperoleh pendapatan dari pelayanan yang dilaksanakan; (6) fokus pada antisipasi terhadap permasalahan pelayanan; dan (7) lebih mengutamakan desentralisasi dalam pelaksanaan pelayanan. Berdasarkan uraian di atas, maka paradigma customer driven government adalah paradigma pelayanan publik yang menempatkan pengguna layanan sebagai hal yang terdepan dan merupakan fokus terpenting dari penyelenggaraan suatu pelayanan atau lebih populer dengan istilah "putting the customer on the driver seat".

Undang-Undang No. 25 Tahun 2009 tentang Pelayanan Publik mendefinisikan pelayanan publik sebagai berikut: Pelayanan publik adalah kegiatan atau rangkaian 
kegiatan dalam rangka pemenuhan kebutuhan pelayanan sesuai dengan peraturan perundang-undangan bagi setiap warga negara dan penduduk atas barang, jasa, dan/atau pelayanan administratif yang disediakan oleh penyelenggara pelayanan publik. Pelayanan publik menurut Roth (1926:1) adalah sebagai berikut : Pelayanan publik didefinisikan sebagai layanan yang tersedia untuk masyarakat, baik secara umum (seperti di museum) atau secara khusus (seperti di restoran makanan).

Sedangkan Lewis dan Gilman (2005:22) mendefinisikan pelayanan publik sebagai berikut: Pelayanan publik adalah kepercayaan publik. Warga negara berharap pelayanan publik dapat melayani dengan kejujuran dan pengelolaan sumber penghasilan secara tepat, dan dapat dipertanggungjawabkan kepada publik. Pelayanan publik yang adil dan dapat dipertanggung-jawabkan menghasilkan kepercayaan publik. Dibutuhkan etika pelayanan publik sebagai pilar dan kepercayaan publik sebagai dasar untuk mewujudkan pemerintah yang baik.

Pengertian pelayanan publik dari wikipedia adalah sebagai berikut: Pelayanan publik adalah istilah untuk layanan yang disediakan oleh pemerintah kepada warga negaranya, baik secara langsung (melalui sektor publik) atau dengan membiayai pemberian layanan swasta. Istilah ini dikaitkan dengan konsensus sosial (biasanya diwujudkan melalui pemilihan demokratis), yaitu bahwa layanan tertentu harus tersedia untuk semua kalangan tanpa mamandang pendapatan mereka. Bahkan apabila layananlayanan umum tersebut tersedia secara umum atau dibiayai oleh umum, layananlayanan tersebut, karena alasan politis atau sosial, berada di bawah peraturan/regulasi yang lebih tinggi daripada peraturan yang berlaku untuk sektor ekonomi. Istilah layanan publik juga merupakan istilah lain untuk layanan sipil.

Terdapat empat unsur penting dalam proses pelayanan publik, yaitu (Bharata, 2004:11):

1. Penyedia layanan, yaitu pihak yang dapat memberikan suatu layanan tertentu kepada konsumen, baik berupa layanan dalam bentuk penyediaan dan penyerahan barang (goods) atau jasajasa (services).

2. Penerima layanan, yaitu mereka yang disebut sebagai konsumen (costomer) atau customer yang menerima berbagai layanan dari penyedia layanan.

3. Jenis layanan, yaitu layanan yang dapat diberikan oleh penyedia layanan kepada pihak yang membutuhkan layanan.

4. Kepuasan pelanggan, dalam memberikan layanan penyedia layanan harus mengacu pada tujuan utama pelayanan, yaitu kepuasan pelanggan. Hal ini sangat penting dilakukan karena tingkat kepuasan yang diperoleh para pelanggan itu biasanya sangat berkaitan erat dengan standar kualitas barang dan atau jasa yang mereka nikmati.

Ciri-ciri pelayanan publik yang baik adalah memiliki unsur-unsur sebagai berikut (Kasmir, 2006:34):

1. Tersedianya pegawai yang baik.

2. Tersedianya sarana dan prasarana yang baik.

3. Bertanggung jawab kepada setiap nasabah (pelanggan) sejak awal hingga akhir.

4. Mampu melayani secara cepat dan tepat.

5. Mampu berkomunikasi.

6. Memberikan jaminan kerahasiaan setiap transaksi.

7. Memiliki pengetahuan dan kemampuan yang baik.

8. Berusaha memahami kebutuhan nasabah (pelanggan).

9. Mampu memberikan kepercayaan kepada nasabah (pelanggan).

Terdapat beberapa asas dalam penyelenggaraan pelayanan pemerintahan dan perizinan yang harus diperhatikan, yaitu (Ratminto dan Winarsih, 2006:245):

1. Empati dengan customers. Pegawai yang melayani urusan perizinan dari instansi penyelenggara jasa perizinan harus dapat berempati dengan masyarakat pengguna jasa pelayanan.

2. Pembatasan prosedur. Prosedur harus dirancang sependek mungkin, dengan 
demikian konsep one stop shop benarbenar diterapkan.

3. Kejelasan tatacara pelayanan. Tatacara pelayanan harus didesain sesederhana mungkin dan dikomunikasikan kepada masyarakat pengguna jasa pelayanan.

4. Minimalisasi persyaratan pelayanan. Persyaratan dalam mengurus pelayanan harus dibatasi sesedikit mungkin dan sebanyak yang benarbenar diperlukan.

5. Kejelasan kewenangan. Kewenangan pegawai yang melayani masyarakat pengguna jasa pelayanan harus dirumuskan sejelas mungkin dengan membuat bagan tugas dan distribusi kewenangan.

6. Transparansi biaya. Biaya pelayanan harus ditetapkan seminimal mungkin dan setransparan mungkin.

7. Kepastian jadwal dan durasi pelayanan. Jadwal dan durasi pelayanan juga harus pasti, sehingga masyarakat memiliki gambaran yang jelas dan tidak resah.

8. Minimalisasi formulir. Formulirformulir harus dirancang secara efisien, sehingga akan dihasilkan formulir komposit (satu formulir yang dapat dipakai untuk berbagai keperluan).

9. Maksimalisasi masa berlakunya izin. Untuk menghindarkan terlalu seringnya masyarakat mengurus izin, maka masa berlakunya izin harus ditetapkan selama mungkin.

10.Kejelasan hak dan kewajiban providers dan curtomers. Hak-hak dan kewajiban-kewajiban baik bagi providers maupun bagi customers harus dirumuskan secara jelas, dan dilengkapi dengan sanksi serta ketentuan ganti rugi.

11.Efektivitas penanganan keluhan. Pelayanan yang baik sedapat mungkin harus menghindarkan terjadinya keluhan. Akan tetapi jika muncul keluhan, maka harus dirancang suatu mekanisme yang dapat memastikan bahwa keluhan tersebut akan ditangani secara efektif sehingga permasalahan yang ada dapat segera diselesaikan dengan baik.
Dari uraian di atas dapat disimpulkan bahwa pelayanan publik adalah bentuk pelayanan yang dilakukan oleh pemerintah baik yang berupa barang maupun jasa guna memenuhi kebutuhan masyarakat ataupun dalam rangka pelaksanaan peraturan perundang-undangan dengan berpedoman pada asas dan prinsip pelayanan.

\section{METODE PENELITIAN}

Penelitian ini adalah penelitian kualitatif, yang mana berakar pada latar alamiah sebagai keutuhan, mengandalkan manusia sebagai alat penelitian, memanfaatkan metode kualitatif, mengadakan alalisis data secada induktif, lebih mementingkan proses dari pada hasil, bersifat deskriptif, memiliki seperangkat kriteria untuk memeriksa keabsahan data, rancangan penelitian bersifat sementara dan hasil penelitiannya disepakati oleh kedua belah pihak yakni peneliti dan responden (Moleong, 1997).

Selain itu, Muhajir (2000) juga mengatakan bahwa penelitian kualitatif adalah penelitian dengan paradigma naturalistik yang dilaksanakan dalam kontek natural, dengan harapan makna yang diangkat memang berasal dari kontek bukan dari pra-konsep, pemaknaan hasil interview dan atau observasi tidak dapat terkait dalam waktu dan konteks tertentu. Dengan demikian dapat dikatakan bahwa penelitian kualitatif merupakan suatu rangkaian investigasi yang lebih mengutakan kealamiahan dan holistik data tanpa ada intervensi atau rekayasa yang dilakukan oleh peneliti. Sehingga, penelitian akan menjadi lebih objektif dan fair dan tidak akan menimbulkan interpretasi yang membingungkan

\section{PEMBAHASAN}

Penelitian ini merupakan penelitian yang bersifat deskriptif tentang kualitas penyelenggaraan pelayanan publik bidang pelayanan public di Kantor Kecamatan Kandangan, sehingga peneliti berusaha untuk menggali, mengungkap kemudian 
mendeskripsikannya. Hasil penelitian ini berupa data-data yang diperoleh melalui wawancara, dokumentasi, dan obervasi. Setelah dilakukan penelitian, dilakukan pembahasan terhadap beberapa hal yang terkait dengan focus penelitian sebagai berikut:

\subsection{Kualitas aparatur Penyelenggaraan Pelayanan Publik di Kantor Kecamatan Kandangan}

Pelayanan publik saat ini menjadi bagian kebutuhan setiap masyarakat. Setiap birokrasi publik perlu berupaya untuk memberikan kualitas pelayanan yang terbaik kepada masyarakat pengguna layanan kantor kecamatan Kandangan. Pelayanan publik pemerintah dalam hal ini kantor Kantor Kecamatan Kandangan, saat ini dirasakan semakin perlu untuk dibenahi dan ditingkatkan, terlebih dalam era seperti ini. Upaya untuk meningkatkan kualitas pelayanan publik yang lebih baik merupakan suatu keharusan yang harus segera dilakukan untuk menciptakan pelayanan lebih efisien, efektif dan sesuai dengan kebutuhan dan aspirasi masyarakat. Kualitas pelayanan publik bidang pelayanan public dapat dilihat dari beberapa indikator, yaitu:

1). Penyediaan sarana dan prasarana fisik (tangibles)

Kualitas pelayanan akan langsung terasa bagus apabila bukti langsung ini diperhatikan, karena hal ini berhubungan dengan penilaian pertama dari masyarakat. Masyarakat yang datang ke Kantor Kecamatan Kandangan akan langsung dihadapkan dengan penilaian fasilitas yang ada dan kebersihan kantor, sehingga kenyamanan masyarakat akan langsung terasa.

Untuk mengatasi kekurangankekurangan pada dimensi tangibles (bukti langsung) diperlukan adanya penambahan atau pengadaan meja dan kursi, penataan ruang tunggu yang lebih baik, menjaga kebersihan kantor, dilakukan pengadaan alat pendingin ruangan (air conditioner), penyediaan tempat sampah, memberikan larangan untuk tidak merokok dalam ruangan, terlebih khusus kepada para aparat kantor kecamatan, penataan atau pengadaan papan informasi / brosur / leaflet yang dapat membantu masyarakat dalam pengurusan administrasi di Kantor Kecamatan Kandangan.

2). Sumberdaya aparatur yang handal (reliability)

Hambatan atau kekurangan yang ditemukan di Kantor Kantor Kecamatan Kandangan adalah lambatnya pengurusan administrasi. Hal ini dikarenakan terbatasnya jumlah pegawai. Kurangnya jumlah pegawai mengakibatkan penyelesaian pengurusan administrasi menjadi lambat, karena satu orang pegawai menangani atau mengurus lebih dari satu jenis pekerjaan. Selain kuantitas pegawai yang kurang, kualitas dari pegawai yang ada pun masih rendah. Menghadapi masalah ini, diperlukan adanya penambahan jumlah pegawai serta peningkatan kualitas pegawai di Kantor Kecamatan Kandangan seperti keilmuan atau wawasan serta kreativitas pegawai melalui peningkatan pendidikan atau pelatihan baik formal maupun nonformal yang mengacu pada peraturan perundang-undangan yang telah ditetapkan serta memperhatikan ketepatan sasaran

3). Penyederhanaan proses / simple process

Hasil penelitian terungkap bahwa masyarakat Kecamatan Kandangan merasa belum puas dengan pelayanan yang diberikan Bagian Pelayanan Umum Kecamatan Kandangan agar pelayanan dapat lebih dipermudah sehingga dalam menangani setiap keluhan masyarakat mudah teratasi.

4). Daya Tanggap (responsiveness) aparatur yang cukup

Aspek daya tanggap yang harus diberikan oleh suatu kantor pelayanan terhadap masyarakat yaitu dengan memberikan respon yang baik, cepat dan tanggap dalam menanggapi setiap keluhan 
masyarakat serta memberikan pelayanan yang maksimal khusunya dalam setiap pelayanan di Kantor Kecamatan Kandangan. Hal ini akan menimbulkan rasa puas kepada masyarakat sebagai penggguna jasa.

5).Menyediakan ruang tunggu dan tempat parkir yang aman / jaminan (Assurance)

Kantor Kecamatan Kandangan Kabupaten Kediri sebagai kantor yang berwenang memberikan pelayanan kepada warga Kandangan. Banyaknya masyarakat yang datang sudah seharusnya mendapatkan kenyamanan selama dalam ruang pelayanan belum ada rasa nyaman karena suasana panas dan kipas angin belum bisa membantu sepenuhnya. Hal ini harusnya kedepanya harus menjadi perhatian yang serius harus segera ditangani.

6). Empati (empathy) aparatur di Kecamatan Kandangan

Proses pelayanan umum wajib diinformasikan secara terbuka agar mudah diketahui dan dipahami oleh masyarakat baik diminta maupun tidak diminta. Karena itu adalah keinginan masyarakat untuk dilayani dengan kejujuran.

Oleh karena itu aparatur yang bertugas harus memberikan penjelasan dengan sejujur-jujurnya, apa adanya dalam peraturan atau norma-norma, jangan menakut nakuti, jangan merasa berjasa dalam memberikan pelayanan agar tidak timbul keinginan untuk mengharapkan imbalan dari masyarakat.

Diharapkan bagi para aparat memerintah khususnya Kantor Kecamatan Kandangan untuk dapat lebih meningkatkan keramahan dan kualitas dalam melayani masyarakat dalam berbagai kepengurusan, sehingga bisa terjalin hubungan yang baik antara aparat pelaksana pelayanan publik dengan masyarakat yang mengrus pelayanan administrasi kependudukan.

\subsection{Strategi eksekutif dalam meningkatkaan kualitas pelayanan di Kantor Kecamatan Kandangan.}

Pelayanan publik merupakan serangkaian aktivitas yang dilakukan pemerintah beserta aparaturnya kepada masyarakat dalam mewujudkan peningkatan kualitas kehidupan masyarakat sekaligus memberikan kepuasan kepada masyarakat yang dilayani. Sebagai salah satu bentuk tanggung jawab pemerintah kepada masyarakat, sudah tentunya suatu pelayanan publik yang diselenggarakan pemerintah harus mencakup seluruh masyarakat yang membutuhkannya, dan yang paling penting lagi adalah bagaimana masyarakat dapat merasakan kepuasan dari layanan yang diberikan kepada mereka.

Penyelenggaraan pelayanan publik yang dilaksanakan oleh aparatur pemerintah dalam berbagai sendi pelayanan antara lain yang menyangkut pemenuhan hak-hak sipil dan kebutuhan dasar penduduk, masih dirasakan belum seperti yang diharapkan oleh masyarakat. Hal ini dapat dilihat antara lain dari banyaknya pengaduan, keluhan masyarakat baik yang disampaikan secara langsung kepada pimpinan unit pelayanan maupun melalui surat pembaca pada berbagai media massa. Dilain pihak masyarakat sebagai unsur utama yang dilayani belum memberikan kontrol yang efektif untuk menjadi unsur pendorong dalam upaya peningkatan kualitas pelayanan publik.

Oleh karena itulah perlu dilakukan berbagai strategi untuk meningkatkan kualitas pelayanan public. Bebrbagai strategi pemerintah Kabupaten Kediri ini sudah diurakan pada anlisis penelitian di atas, sehingga pada akhirnya tujuan dari pelaksanaan pelayanan publik itu akan tercapai dan memberikan tingkat kepuasan kepada masyarakat yang menerimanya.

\section{E. KESIMPULAN DAN REKOMENDASI}

\subsection{Kesimpulan}

Berdasarkan hasil penelitian dan pembahasan yang telah dilakukan mengenai kualitas pelayanan publik di Kecamatan 
Kandangan dapat diambil kesimpulan sebagai berikut :

1. Berdasarkan hasil penelitian yang dilakukan untuk menilai kinerja aparatur di Kantor Kecamatan Kandangan dilihat dari indikator kualitas pelayanan publik yang diberikan kepada masyarakat yaitu: Sarana dan prasarana fisik (tangible), sumber daya aparatur yang handal (reliability), penyederhanaan proses (simple process), daya tanggap (responsiveness)aparatur yang cukup, penyediaan ruang tunggu dan tempat parkir yang aman / jaminan (assurance) serta empati (empathy) aparatur di kecamatan kandangan. Implementasi keenam indikator ini merupakan tolok ukur kinerja yang sudah dilakukan oleh aparatur Kecamatan Kandangan. Maka dapat dikatakan bahwa rata-rata masyarakat menilai sudah relatif baik.

2. Strategi pemerintah Kabupaten Kediri dalam Meningkatkan Kualitas Penyelenggaraan Pelayanan Publik di kecamatan Kandangan adalah dengan cara:

- Mengadakan program penyuluhan melalui kepala Dusun kepada masyarakat, untuk membantu penyebaran dan pemahaman informasi kepada masyarakat, mengenai hal-hal yang berkaitan dengan kegiatan pelayanan.

- Menyelenggarakan pelayanan yang tidak memberatkan dan menyulitkan masyarakat Kandangan.

- Meningkatkan profesionalisme masing-masing pegawai di Kecamatan Kandangan.

- Mengajukan pengadaan fasilitas penunjang pelayanan publik.

\subsection{Rekomendasi}

Berdasarkan kesimpulan di atas, maka penulis dapat memberikan saran sebagai berikut :
1. Kecamatan Kandangan harus lebih meningkatkan kualitas pelayanan yang dianggap kurang memuaskan dalam proses pelayanan yaitu sarana dan prasarana fisik (tangible) agar masyarakat dapat merasa puas dan nyaman saat melaksanakan pelayanan.

2. Mengadakan program penyuluhan melalui kepala Dusun, RT, RW dan kepada masyarakat, untuk membantu penyebaran dan pemahaman informasi kepada masyarakat, mengenai hal-hal yang berkaitan dengan kegiatan pelayanan di Kecamatan Kandangan.

3. Menyelenggarakan pelayanan yang tidak memberatkan dan menyulitkan masyarakat Kandangan, pelayanan yang sederhana dan mudah dipahami.

4. Memberikan pelayanan yang terbuka tethadap masyarakat baik biaya pelayanan dan prosedur pelayanannya

5. Memberikan pelayanan yang akuntabel sesuai dengan ketentuan yang berlaku.

\section{F. REFERENSI}

Achmat Batinggi. 1999. Manajerial Pelayanan Umum. Jakarta: Universitas Terbuka.

Agus Dwiyanto. 2006. Mewujudkan Good Governace Melayani Publik. Yogyakarta: UGM Press.

Arikunto, Suharsimi. 1995. Manajemen Penelitian. PT Rineka Cipta. Jakarta.

Basrowi dan Suwandi. 2008. Memahami Penelitian Kualitatif. Jakarta: Rineka Cipta.

Charles O. Jones. 1991. Pengantar Kebijakan Publik. Rajawali Pers. Jakarta.

Davis, K. and Wether, Jr, W. B., Human resources and Personel Management, Third Edition, McGraw-Hill Book Company, 1996.

Djatmiko, Y; H., 2002, Perilaku organisasi. Bandung: Alfabeta.

Eny Kusdarini. 2011. Dasar -Dasar Hukum Administrasi Negara dan Asas - Asas 
Umum Pemerintahan yang Baik. Yogyakarta: UNY Press.

Gibson, James L. et al., Organisasi, Binarupa Aksara, Jakarta, 1996

Gibson, J. L., Ivancevich, J. M., and Donnely, Jr, J. H. , Organization: Behavior, Structur, Processes, Ninth Edition, Irwin, 1999

Hardiyabsyah. 2011. Kualitas Pelayanan Publik Konsep, Dimensi, Indikator, dan Implementasinya. Yogyakarta: Gava Media.

Imran, Ali, 1995, Pembinaan pegawai di Indonesia. Jakarta: Pustaka Jaya

Inu Kencana Syafiie. 1999. Ilmu Administrasi Publik. Jakarta: PT. Rineka Cipta.

Keputusan Menteri Pendayagunaan Aparatur Negara Nomor 63 Tahun 2003 tentang Pelayanan Publik

Keputusan Menteri Pendayagunaan Aparatur Negara Nomor 63 Tahun 2004 tentang Pelayanan Publik

Lexy J. Maleong. 2007. Metode Penelitian Kualitatif. Bandung: PT. Remaja Rosdakarya.

Litjan Poltak Sinambela, dkk. 2011. Reformasi Pelayanan Publik Teori, Kebijakan, Implementasi. Jakarta: Bumi Aksara.
Peraturan Daerah Kab. Kediri No. 7 tahun 2009 tentang penyelenggaraan Pendaftaran Penduduk dan Pencacatan Sipil dalam Kerangka Sistem Informasi Pelayanan publik(SIAK).

Ranupandoyo, Heidjrachman \& Suad Husnan. 1984. Sumber Daya Manusia. BPFE. Yogyakarta.

Ratminto dan Atik Septi Winarsih. 2006. Manajemen Pelayanan.Yogyakarta : Pustaka Pelajar.

Saefullah. 1999. Konsep dan Metode Pelayanan Umum yang Baik, dalam Jurnal Ilmu Sosial dan Ilmu Politik. Sumedang: FISIP UNPAD.

Sanapiah Azis. 2000. Pelayanan yang berorientasi kepada kepuasan masyarakat jurnal Administrasi Negara Vol 6 Nomor 1.

Siagian, Sondang P, 1996, Manajemen Sumber Daya Manusia, Bumi Aksara, Jakarta.

Sondang P Siagian. 2000. Administrasi Pembangunan Konsep, Dimensi, Stateginya. Jakarta: Bumi Aksara.

Subrata Sumadi. 2012. Metode penelitian. PT Raja Grafindo Persada: Jakarta.

Sukarna, 1990, Prinsip-Prinsip Administrasi Manajemen, CV. Mandar Maju, Bandung.

Sugiyono.2004. Metode Penelitian Administrasi. Alfabeta. Bandung. 